\title{
ABOUT THE AUTHORS
}

\section{The Editors}

James E. Groccia is director of the Biggio Center for the Enhancement of Teaching and Learning and associate professor of higher education in the Department of Educational Foundations, Leadership, and Technology at Auburn University. In addition to faculty development work, he teaches graduate courses on teaching and higher education and coordinates the university's Graduate Certificate in College and University Teaching. He is a former POD Network president and received his Ed.D. in educational psychology and guidance from the University of Tennessee. He is coauthor with Mary Stuart Hunter of The First-Year Seminar: Designing, Implementing, and Assessing Courses to Support Student Learning and Success: Volume II-Instructor Training and Development (2012), and author of The College Success Book: A Whole-Student Approach to Academic Excellence (1992). He is coeditor with Mohammed Alsudairi and Bill Buskist of The Handbook of College and University Teaching: A Global Perspective (2012); with Bill Buskist of Evidence-Based Teaching (2011); and with Judy Miller of On Becoming a Productive University: Strategies for Reducing Costs and Increasing Quality in Higher Education (2005), Student Assisted Teaching: A Guide to FacultyStudent Teamwork (2001), and Enhancing Productivity: Administrative, Instructional, and Technological Strategies (1998). He can be reached at groccje@auburn.edu.

0

Laura Cruz is associate professor of history and director of the Coulter Faculty Commons at Western Carolina University, a large and productive teaching and learning center that won a national award in 2010 from Campus Technologies magazine. In addition to publications in her discipline, European history, she is the author of articles on faculty development, educational technology, history pedagogy, graduate student development, peer review, and (especially) the Boyer model of scholarship. She currently serves as editor-in-chief of MountainRise, the international 
journal of the scholarship of teaching and learning (SoTL). Cruz has won multiple teaching and engagement awards and is the principal organizer of an annual nationwide retreat on the Boyer model of scholarship. She regularly participates in professional organizations including POD, Southern Regional Faculty and Instructional Development, International Scholarship of Teaching and Learning, and those related to her discipline of history. She is frequently invited to present, provide workshops and invited sessions, or consult on topics of SoTL, the Boyer model of scholarship, and faculty center organizational models. She can be reached at lcruz@email.wcu.edu.

\section{The Contributors}

Dorothe J. Bach is associate professor and assistant director at the University of Virginia's Teaching Resource Center where she directs the Excellence in Diversity Fellows Program for new and underrepresented faculty and supports initiatives designed to advance excellence in teaching and learning. She also teaches literature courses in the university's German Department and Comparative Literature Program. Her publications include articles on teaching and learning, as well as faculty development. She can be reached at bach@virginia.edu.

O

Daniel Barbezat is professor of economics at Amherst College. He has been a visiting professor at Northwestern University and Yale University and has taught in the summer program at Harvard University. In 2004, he won the J. T. Hughes Prize for Excellence in Teaching Economic History from the Economic History Association. His approach to teaching economics classes has been featured in the Boston Globe and U.S. News of World Report, as well as on NPR's program Here and Now. $\mathrm{He}$ is executive director of the Center for Contemplative Mind in Society and is currently writing a handbook of contemplative practices in higher education with Mirabai Bush, editing a collection of papers with Arthur Zajonc, and working on a book provisionally entitled Wanting. He can be reached at dpbarbezat@amherst.edu.

O

Nancy H. Barry is professor of music education in the Auburn University College of Education. She also served as professor, graduate coordinator, and chair of music education at the University of Oklahoma, where she received the Henry Daniel Rinsland Memorial Award for Excellence in 
Educational Research and was awarded a Presidential Professorship. Her research interests include faculty professional development, curriculum, and arts education. She can be reached at barrynh@auburn.edu.

O

Allison Boye is the director of the Teaching Effectiveness and Career enHancement (TEACH) Program at Texas Tech University's Teaching, Learning, and Professional Development Center. She is the chair of the POD Innovation Award Committee and on the 2012 POD Conference Team and also currently serves on the executive council of the Texas Faculty Development Network. Her recent publications focus on consulting practices, graduate student development, peer observation, and instructor response to feedback. She can be reached at allison.p.boye@ttu.edu.

0

Edward J. Brantmeier is assistant director of the Center for Faculty Innovation and assistant professor in the Learning, Technology, and Leadership Education Department at James Madison University. A former Fulbright Scholar, he teaches multicultural education courses, faculty development work, and researching issues related to curriculum development, diversity, critical theoretical approaches, technology, sustainability, and contemplative practices in $\mathrm{K}-20$ contexts. He can be reached at brantmej@jmu.edu.

○

Allison BrckaLorenz is an assistant research scientist at the Indiana University Center for Postsecondary Research working primarily with the National Survey of Student Engagement and the Faculty Survey of Student Engagement. Her research interests include the teaching and learning of college students and accompanying issues that faculty face, as well as the socialization and professional development of graduate students and faculty members. She can be reached at abrckalo@indiana.edu.

○

Derek Bruff is director of the Vanderbilt University Center for Teaching and a senior lecturer in the Department of Mathematics. Bruff consults regularly with faculty in a variety of disciplines about educational technology and other teaching and learning topics. His research interests include classroom response systems (clickers), visual thinking, student motivation, and social pedagogies. He blogs on these topics at derekbruff.com, and his book, Teaching with Classroom Response Systems: Creating Active 
Learning Environments, was published by Jossey-Bass in 2009. Bruff has taught at Harvard University and has a Ph.D. in mathematics from Vanderbilt University. He can be reached at derek.bruff@Vanderbilt.edu.

O

William E. Bubro is professor and chair of chemistry and George E. Pake Professor in Arts and Sciences at Washington University in St. Louis. He teaches general chemistry, inorganic chemistry, and solid-state and materials chemistry. His research investigates quantum confinement effects and exciton/charge transport in colloidal semiconductor nanocrystals, including quantum dots, rods, wires, and belts. He can be reached at buhro@wustl.edu.

O

Eddie Cole is a project associate for the Faculty Survey of Student Engagement and a doctoral candidate in higher education at Indiana University, where he also holds a master's degree in higher education. His primary research focus is on the rhetoric of college presidents and student unrest in the 1960s and the historical roots of and current issues faced by distinct mission institutions. He can be reached at coleer@indiana.edu.

○

Michelle Corvette holds a doctorate in educational psychology, an M.F.A. in studio art, and is currently pursuing a second doctoral degree in visual art research at Goldsmiths, University of London. She previously served as the assistant director of the Tennessee Teaching and Learning Center. She can be reached at michellecorvette@nyu.edu.

\section{O}

Amber Dailey-Hebert is an associate professor of adult education at Park University and serves as an international consultant for educational projects in Europe and Africa. Her work and research is focused on adult learners, distance education and training, and grant-funded projects that serve working professionals. She chairs the Research Committee for the Association of Continuing and Higher Education, has published numerous articles and book chapters, and was the founding director of the Center for Excellence in Teaching and Learning, which serves over sixteen hundred full- and parttime faculty worldwide. She can be reached at adailey@park.edu.

$\circ$

Dannielle Joy Davis, a graduate of the University of Illinois at UrbanaChampaign and associate professor of educational leadership, policy, and 
law at Alabama State University, has studied and conducted research in Ghana, South Africa, Egypt, Germany, the Netherlands, and Belgium. Her interdisciplinary, $\mathrm{K}-20$ research examines the experiences of marginalized groups in educational settings and the role of organizational policy and practice in the promotion or inhibition of egalitarian academic and occupational outcomes. She serves as an associate editor for Learning for Democracy: An International Journal of Thought and Practice, which is sponsored by the American Educational Research Association Special Interest Group, Democratic Citizenship in Education. She can be reached at djdavis@illinoisalumni.org.

\section{o}

Michele DiPietro is executive director of the Center for Excellence in Teaching and Learning and associate professor of statistics at Kennesaw State University. His research interests focus on learning sciences, diversity and inclusion, the consultation process, statistics education, student evaluations of teaching, and teaching in times of tragedies. He is the 2012-2013 president of the POD Network. He can be reached at mdipi etr@kennesaw.edu.

Emily Donnelli-Sallee is an associate professor of English at Park University, where she also serves as faculty director of the Center for Excellence in Teaching and Learning. In this role, she devises resources and programs to support teaching excellence across disciplines and instructional modalities, and she provides leadership for a crossdisciplinary faculty advisory council. She teaches courses in writing and rhetoric and serves as editor of Missouri Campus Compact's Journal of Public Scholarship in Higher Education. Her research examines the ways that public sphere theory can inform civic engagement pedagogies, particularly in first-year composition. She can be reached at emilyd @park.edu.

0

Peter E. Doolittle is director of the Center for Instructional Development and Educational Research and associate professor of educational psychology in the Department of Learning Sciences at Virginia Tech. He is also the executive editor of the International Journal of Teaching and Learning in Higher Education, co-executive editor of the International Journal of ePortfolio, and associate editor of the International Journal of Cyber Behavior, Psychology and Learning. His current research focuses 
include multimedia learning, working memory capacity, and the learning efficacy of Web 2.0 technologies. He can be reached at pdoo@vt.edu.

Elizabeth L. Evans is the director of the Center for Excellence in Learning and Teaching and an assistant professor of business at Concordia University Wisconsin. Her chapter is based on her doctoral research at the University of Wisconsin-Milwaukee and her presentation on this work, which was recognized with the POD Network's 2011 Robert J. Menges Award. She serves as a Teagle Assessment Scholar with the Center of Inquiry in the Liberal Arts at Wabash College. She can be reached at elizabeth.evans@cuw.edu.

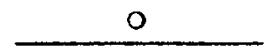

Hyacinth E. Findlay is professor of instructional leadership at Alabama State University. Her main areas of research include teacher concerns, educational leadership, and succession planning. She has served as a public school and higher education administrator. She has traveled widely on international educational trips, including a Fulbright award to Senegal and the Gambia. She can be reached at hfindlay@alasu.edu.

○

Beth A. Fisher is associate director of the Teaching Center and Lecturer in Women, Gender, and Sexuality Studies at Washington University in St. Louis. Her work focuses on helping graduate students develop pedagogical knowledge and expertise and on developing teaching methods that can help undergraduates and graduate students improve their writing skills. She teaches courses in American literature and gender studies. She can be reached at bfisher@wustl.edu.

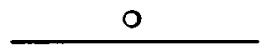

Deborah J. Frank is a science writer in the Department of Obstetrics and Gynecology at Washington University in St. Louis. Her work focuses on improving the quality of research manuscripts and grant proposals in terms of both the science and the writing. She can be reached at DFrank22@wustl.edu.

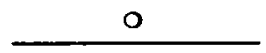

Regina F. Frey is professor of the practice in chemistry, director of the Teaching Center, and associate director of the Center for Integrative Research in Cognition, Learning, and Education at Washington 
University in St. Louis. She teaches general chemistry, Women in Science, and a peer leader training course. She works with colleagues in chemistry, cognitive science, and education to conduct research focused on grouporiented, student-centered pedagogies for the teaching of science, technology, engineering, and mathematics. She can be reached at gfrey@ wustl.edu.

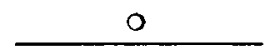

Chutney Guyton holds a Ph.D. in educational leadership and policy and an M.B.A. degree. She is an academic adviser at North Carolina Central University, Durham. Previously she was a graduate researcher with the Tennessee Teaching and Learning Center. She can be reached at chutney .guyton@nccu.edu.

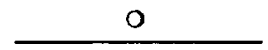

Cameron J. Harris is an associate instructor in the School of Education and graduate assistant in the Office of the President, Indiana University, Bloomington, where he is completing his Ph.D. in higher education and student affairs. His research interests include the faculty profession, the educational pipeline to the professoriate, African Americans in higher education, and curriculum in higher education. He can be reached at harriscj@indiana.edu.

Natasha Haugnes is a faculty developer at the Academy of Art University in San Francisco. She holds an M.A. from San Francisco State University in Teaching English to Speakers of Other Languages and has authored two English as a Second Language textbooks. Her recent professional presentations and research focus on fostering creativity in the classroom, as well as using and creating rubrics to effectively assess art and design work. She can be reached at nhaugnes@gmail.com.

Jennifer $H$. Herman is director of instructional support at Niagara University. She holds a master's degree in international training and education from American University and a Ph.D. in higher education from the State University of New York at Buffalo. Her research focuses on online education, faculty development, organizational development in higher education, and curriculum design. She has developed extensive curricula and training programs for the U.S. Department of State and the 
New York State Small Business Development Center. She can be reached at jherman@niagara.edu.

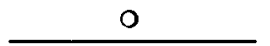

Matthew Holley is a visiting lecturer at the Indiana University School of Medicine, where he serves as the curriculum and instructional design director for the Department of Family Medicine. He is completing his Ph.D. in higher education and student Affairs at Indiana University, Bloomington. His research focuses on curriculum development, college teaching and learning, and the faculty profession, with a particular emphasis on the experiences of lesbian, gay, bisexual, and transgender faculty members. He can be reached at maholley@iupui.edu.

o

Hoag Holmgren is executive director of the POD Network in Higher Education. His professional interests include collaborative leadership, higher education and the arts, and assessment and the arts. He taught creative writing for several years at the University of Colorado-Boulder and has published and presented on assessing student work in the arts. His nonfiction, fiction, and poetry have appeared in numerous literary journals. He can be reached at hoag.holmgren@gmail.com.

o

Jillian Kinzie is associate director of the Indiana University Center for Postsecondary Research and NSSE Institute. She leads project activities on the effective use of student engagement data to improve educational quality, and serves as a research associate on the National Institute for Learning Outcomes Assessment, an initiative to study assessment in higher education and assist institutions in adopting promising practices in the assessment of college student learning outcomes. She can be reached at jikinzie@indiana.edu.

O

Melissa Langridge is the user education coordinator at Niagara University Library. She has a master's degree in library science and is obtaining a master's degree in teacher education at Niagara University. A strong foundation in educational theory and practice, along with her interest in technology, supports the ongoing development of the library's instruction curriculum. Other interests include information literacy, online learning, and instructional game design. She can be reached at mlangridge@niagara.edu. 
$\mathrm{O}$

Carol Lauer is chair and professor of anthropology at Rollins College. She received her Ph.D. in anthropology from the University of Michigan and teaches courses on human evolution and medical anthropology. As a result of her work evaluating the quality of her colleagues' teaching as a department chair and member of her college's tenure and promotion committee, she has developed an academic interest in assessment of teaching by students. She can be reached at clauer@rollins.edu.

$\mathrm{O}$

Virginia S. Lee is principal and senior consultant of Virginia S. Lee \& Associates, a consulting firm specializing in educational development in higher education. Previously she held administrative positions with teaching centers at the University of North Carolina at Chapel Hill and North Carolina State University. She is a former president of the Professional and Organizational Development Network in Higher Education. She edited Inquiry-Guided Learning (2012) and Teaching and Learning Through Inquiry: A Guidebook for Institutions and Instructors (2004). She can be reached at vslee@virginiaslee.com.

$\mathrm{O}$

Cuiting $L i$, born in China, received elementary to college education in China. After teaching in a university for three years, she was admitted to Auburn University to obtain her master's and Ph.D. in human development and family studies. After graduation, she worked as an assistant professor in the State University of New York, Oneonta. Currently she is an assistant professor at the University of Wisconsin, Stevens Point. She can be reached at cli@uwsp.edu.

\section{0}

Marty Loy is dean of the College of Professional Studies at the University of Wisconsin-Stevens Point, where he also served as associate dean in the School of Health Promotion and Human Development and as the Focus on Teaching program coordinator. His research areas are stress management, childhood grief, and faculty development. He is the author of Childhood Stress: A Handbook for Parents, Teachers and Therapists (2009). He won the University Excellence in Teaching Award in 2001. He can be reached at mloy@uwsp.edu. 
B. Jean Mandernach is a research professor and director of the Center for Innovation in Research and Teaching at Grand Canyon University. Her research focuses on enhancing student learning through assessment and innovative online instructional strategies. In addition, she has interests in examining the perception of online degrees, the quality of online course offerings, and the development of effective faculty evaluation models. She received her B.S. in comprehensive psychology from the University of Nebraska at Kearney, an M.S. in experimental psychology from Western Illinois University, and a Ph.D. in social psychology from the University of Nebraska at Lincoln. She can be reached at jean.mandernach @gcu.edu.

o

Kathryn G. Miller is professor and chair of biology at Washington University in St. Louis. She is conducting a study of the pedagogical methods she developed in an upper-division, writing-intensive course in developmental biology. Since 2004, she has been the principal investigator on a Howard Hughes Medical Institute grant supporting improvements in undergraduate science education. Her research investigates structural components of cells that mediate movement, shape, and organization. She can be reached at miller@wustl.edu.

O

Richard N. Muthiah is dean of learning support services at George Fox University, where he is responsible for disability services and the student learning center. He received a Ph.D. in higher education from Indiana University, Bloomington, while working as a project associate for the NSSE Institute. His areas of interest include student learning, cocurricular contributions to student learning, service-learning, campus cultures, and Christ-centered thought and practice in higher education. He can be reached at rmuthiah@georgefox.edu.

O

Rachel K. Niemer oversees digital publicity efforts and leads the graduate student instructor teaching orientation and the University of Michigan's involvement in the Center for the Integration of Research, Teaching and Learning Network. Previously she taught chemistry at Gustavus Adolphus College and courses on pedagogy to undergraduate peer leaders at University of Rochester. She has a Ph.D. in chemistry from Caltech and did postdoctoral work at the University of Rochester. She can be reached at rkniemer@umich.edu. 
Linda B. Nilson is founding director of the Office of Teaching Effectiveness and Innovation at Clemson University and a previous editor of To Improve the Academy (Vols. 25-28). She is also author of The Graphic Syllabus and the Outcomes Map: Communicating Your Course (2007) and Teaching at Its Best: A Research-Based Resource for College Instructors, now in its third edition (2010). She gives keynotes and workshops at conferences, colleges, and universities both nationally and internationally. She can be reached at nilson@clemson.edu.

O

Megan M. Palmer is assistant dean for faculty affairs and professional development at the Indiana University (IU) School of Medicine. She is also an assistant professor of general internal medicine and educational leadership and policy studies at the IU School of Education in Indianapolis. Along with her colleagues Genevieve Shaker and Nancy Chism, she was selected for POD's Robert Menges Award. Her research focuses on college teaching, faculty development, and faculty vitality. She can be reached at mmpalmer@indiana.edu.

0

Allison Pingree is director of professional pedagogy at the Harvard Kennedy School, after serving as director of the Vanderbilt University Center for Teaching for thirteen years. She holds a Ph.D. in English and American literature from Harvard; taught there in English, history, literature, and expository writing; and served as an acting associate director at the Derek Bok Center for Teaching and Learning. Her research interests include interdisciplinary teaching, learning, and collaboration; leadership and organizational change; and contemplative pedagogy. Her passion as an educator lies in cultivating ways to integrate cognitive, affective, and embodied forms of learning to promote individual and social change. She can be reached at allison_pingree@harvard.edu.

0

Kristen A. Renn is associate professor of higher, adult, and lifelong education at Michigan State University. Her teaching and research focus on areas of identity in higher education. She has published books, articles, and chapters on the topics of mixed-race college students; lesbian, gay, bisexual, and transgender issues; and promoting success for diverse learners in the United States and other countries. She is associate editor for international research and scholarship of the Journal of College Student 
Development and a member of the governing board of the American College Personnel Association. She can be reached at renn@msu.edu.

O

Tony Ribera is a project associate for the NSSE Institute for Effective Educational Practice and a doctoral candidate in higher education at Indiana University. His dissertation explores the formal student affairs master's curriculum and how future professionals are prepared to gather, analyze, interpret, and disseminate evidence of teaching and learning. $\mathrm{He}$ can be reached at aribera@indiana.edu.

Kelly Schoonaert is assistant professor of health promotion and human development at the University of Wisconsin Stevens Point. She earned her Ed.D. at Ball State University in 2003 with a cognate in wellness. She is a certified intrinsic coach and enjoys helping people find their strengths and inspirations. She can be reached at Kelly.Schoonaert@uwsp.edu.

○

David W. Schumann is the inaugural director of the Tennessee Teaching and Learning Center and holds the William J. Taylor Distinguished Professorship of Business at the University of Tennessee. His research interests are focused on consumer attitudes and persuasion and his teaching on leadership and teaching preparation of Ph.D. students. He has a master's degree and $\mathrm{Ph} . \mathrm{D}$. in social psychology, a master's degree in counseling education, and a bachelor's degree in education. He can be reached at dschuman@utk.edu.

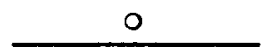

Genevieve G. Shaker is assistant professor of philanthropic studies at the Center on Philanthropy at Indiana University and director of communications and creative services for the IU School of Liberal Arts at IUPUI. With her colleagues Nancy Chism and Megan Palmer, she was selected for POD's Robert J. Menges Award. Her work was also recognized as the Association for the Study of Higher Education's Bobby Wright Dissertation of the Year. Her current research interests center on philanthropy and faculty work. She can be reached at gshaker@iupui.edu.

0

Martin Springborg is a faculty member in the Minnesota State Colleges and Universities System (MnSCU), where he teaches photography and art 
history. He has also worked in the field of educational development for eight years, at Inver Hills Community College, and later as a program director at MnSCU's system office. His current photographic work is focused on teaching and learning in higher education. Other research interests include assessment methods used in arts disciplines. He can be reached at martin.springborg@gmail.com.

$\mathbf{O}$

Dorian Stiefel is a doctoral student in political science at the University of Tennessee and a community volunteer with the Tennessee Teaching and Learning Center. She can be reached at dstiefel@utk.edu.

Suzanne Tapp is director of the Teaching, Learning, and Professional Development Center at Texas Tech University. She is a member of the POD Core Committee (2011-2014) and the past chair of the Texas Faculty Development Network. She can be reached at suzanne.tapp@ttu.edu.

0

Krista Terry is assistant professor of instructional technology in the Department of Leadership and Educational Studies at Appalachian State University. She is an associate editor of the International Journal of Teaching and Learning in Higher Education and the publications officer for the Applied Research in Virtual Environments for Learning SIG of the American Educational Research Association. Her current research focus includes aspects of community and collaboration in virtual learning environments, as well as issues related to cognition in technology-mediated learning environments. She can be reached at terrykp@appstate.edu.

$\mathrm{O}$

Roben Torosyan is associate director for the Center for Academic Excellence and assistant professor of educational studies and teacher preparation at Fairfield University. He has facilitated seventy-eight workshops at conferences and institutions, including Columbia, New York University, and Harvard, on topics such as facilitating controversial conversations, giving critical feedback on teaching, and managing resistance. He holds a Ph.D. in cultural studies, philosophy, and education from Teachers College, Columbia University. He can be reached at rtorosyan @fairfield.edu. 
Katherine Valle is a graduate student earning a master's of public policy and master's of arts in higher education at the Gerald R. Ford School of Public Policy and the Center for the Study of Higher and Postsecondary Education at the University of Michigan. She has worked in policy development in both the United States and abroad. Her interests center on polices that increase student success such as access, college affordability, and the promotion of civic engagement and leadership development opportunities. She can be reached at kvalle@umich.edu.

Nancy Van Note Chism is professor emerita of higher education and student affairs in the Indiana University School of Education, Indianapolis. She has worked in professional and organizational development at both Ohio State University and Indiana University-Purdue University Indianapolis for over twenty-five years. Her interests include professional and organizational development, the faculty profession, international higher education, and college teaching and learning. She can be reached at nchism@iupui.edu.

0

Sterling $K$. Wall, associate professor of family and consumer sciences, has taught ten years in family science in the University of Wisconsin System and has led his college students on several service-learning trips to Mexico and Nicaragua. He seeks to simultaneously increase students' awareness of the world outside the United States, while helping them to see themselves, their families, and their own culture more clearly. He can be reached at Sterling.Wall@uwsp.edu.

o

C. Edward Watson is associate director of the Center for Instructional Development and Educational Research at Virginia Tech. He holds a Ph.D. in instructional design and technology. His current research interests include digital native mythologies, e-portfolio pedagogies and practices, distance learning, and the pedagogy of things. He is the founding co-executive editor of the International Journal of ePortfolio and the managing editor of the International Journal of Teaching and Learning in Higher Education. He can be reached at edwatson@vt.edu.

Mary Wright is director of assessment and an associate research scientist at the Center for Research on Learning and Teaching. In this capacity, she 
works with the University of Michigan's faculty and academic units on assessment of student learning, evaluation of educational initiatives, and the scholarship of teaching and learning. She is the author of Always at Odds? Creating Alignment Between Faculty and Administrative Values (2008). She is a member of POD's Core Committee and cochairs the Graduate and Professional Student Development Committee. She has a Ph.D. in sociology from the University of Michigan. She can be reached at mcwright@umich.edu. 